\title{
КЛІНІЧНА МЕДИЦИНА
}

DOI: $10.26693 / \mathrm{jmbs} 03.01 .080$

УДК 616.12-005.4-089.1:616.132.2-007.271]-036.8

Аксьонов Є. В., Гуменюк Б. М., Головенко В. Б.

\section{ВІДДАЛЕНІ КЛІНІКО-АНГІОГРАФІЧНІ РЕЗУЛЬТАТИ РЕКАНАЛІЗАЦІЇ КОРОНАРНИХ АРТЕРІЙ МАЛОГО ДІАМЕТРУ У ПАЦІІЕНТІВ 3 ІШЕМІЧНОЮ ХВОРОБОЮ СЕРЦுЯ}

\author{
Національний інститут серцево-судинної хірургії \\ ім. М. М. Амосова НАМН України, Київ, Україна
}

nika.golovenko@gmail.com

Робота присвячена вивченню результатів ендоваскулярних процедур при реваскуляризації коронарних артерій малого діаметра.

В дослідження увійшло 315 пацієнтів віком $66,96 \pm 1,81$ років, 3 середнім діаметром істинного

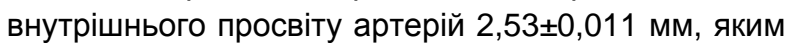
була проведена реваскуляризація міокарду за допомогою стентування або шляхом перкутанної транслюмінальної балонної ангіопластики.

В результаті проведених досліджень було встановлено, що у пацієнтів з ексцентричним типом стенозу, яким була виконана балонна ангіопластика, рестеноз у віддаленому післяопераційному періоді реєструвався на $21 \%$ частіше, відносно подібного контингента пацієнтів з імплантованими стентами. До того ж, рестеноз стенозованої ділянки коронарної артерії діаметром >15 мм у віддаленому періоді зустрічався на 14,9\% частіше при проведенні перкутанної транслюмінальної балонної ангіопластикі. Частота віддаленого рестенозу (при складній морфології вихідного пошкодження артерій) в групі стентування була на 14,2\% нижча, ніж в групі перкутанної транслюмінальної балонної ангіопластикі.

Ключові слова: ішемічна хвороба серця, реканалізація коронарних артерій.

Зв'язок роботи 3 науковими програмами, планами, темами. Дана робота $€$ фррагментом НДР «Система забезпечення безпеки при рентгенендоваскулярних втручаннях у хворих на IXC», № держ. реєстрації 0114U006459.

Вступ. Серцево-судинні захворювання $є$ однією з головних причин смертності в усьому світі.
Основний внесок в її структуру належить ішемічній хворобі серця (IXC), яка стала найбільшою загрозою для здоров'я населення в усьому світі [1].

Так, у країнах з високим рівнем доходу від IXC щорічно помирає 1 млн. 420 тисяч осіб [2], а витрати на лікування цього захворювання тільки в США становлять 165,4 млн. доларів [1].

Україна посідає одне з перших місць в Європі за показниками смертності від хвороб системи кровообігу (459,48 на 100000 населення), які істотно перевищують аналогічні показники у Франції (30,08 на 100000 населення), Німеччині (75,09 на 100000 населення), Польщі (88,37 на 100000 населення), Великобританії (76,11 на 100000 населення) [3].

За період 2008-2012 рр. показники поширеності IXC в Україні серед дорослих поступово збільшувалися (на 6,7\%), і досягли 24 088,1 особи на 100 тис. населення. Питома вага працездатного населення у структурі поширеності й захворюваності IXC, серед усіх дорослих, становить відповідно $28,9 \%$ і $43,9 \%$ [3-5].

В даний час вважається загальновизнаним, що стентування та ангіопластика коронарних артерій (КА) € ефективними методами лікування IXC, що дозволяють у великому відсотку випадків досягти адекватного відновлення кровотоку у вінцевих судинах, уражених стенозуючим атеросклерозом.

При цьому слід зазначити, що черезшкірні ендоваскулярні коронарні втручання здатні забезпечити адекватну реваскуляризацію міокарда [6] і в значній мірі зменшити потребу в хірургічному коронарному шунтуванні, а у деяких пацієнтів бути повноцінною альтернативою аортокоронарному шунтуванню [7]. 
Однак незважаючи на впровадження нових технологій і методик в інтервенційній терапії IXC, використання сучасних стентів і балонів, розробкою високоефективних методів фрармакологічної підтримки процедури, уточненням показань до ії проведення та накопиченням досвіду фахівців, відсоток дрібних і великих перепроцедуральных ускладнень при проведенні коронарних ангіопластик складає 3,9\% і 10,4\% відповідно [8].

Це великою мірою відноситься і до питання реваскуляризації КА малого діаметра. При цьому слід відмітити, що пацієнти з такими артеріями складають значну частину популяції.

Так, за даними багатьох авторів від 30\% до 50\% КА, які потребують стентування, мають діаметр менше 3 мм $[9,10]$.

В останні роки, з накопиченням досвіду інтервенційних втручань, появою нових моделей стентів і дезагрегантів, частота госпітальних ускладнень ангіопластики КА малого діаметра значно знизилася.

У роботі R. Diletti і співавт. вказуеться, що протягом двохрічного періоду спостереження не спостерігалося достовірної різниці в ускладненнях при проведенні стентування між групою пацієнтів з коронарними судинами малого діаметра і при стентуванні КА діаметром більше 3 мм [11]. Однак, як показали дані дослідження «PICCOLETO study», відстрочений рестеноз при малому калібрі КА спостерігається в 32,1\% випадків [12].

Таким чином, усі вищевикладені факти диктують необхідність подальшого дослідження, систематизації, впровадження нових підходів у терапію та профілактику ускладнень, пов'язаних з інтервенційними процедурами у пацієнтів з IXC, що мають малий діаметр коронарних артерій.

Метою даної роботи було вивчення віддалених результатів ендоваскулярних процедур при реваскуляризації коронарних артерій малого діаметра.

Об'єкт і методи дослідження. В дослідження увійшло 315 пацієнтів з IXC, яким на базі рентгенангіографічного відділення Національного інституту серцево-судинної хірургії імені М. М. Амосова НАМН України проводилися діагностичні та лікувальні інтервенційні процедури з приводу даної патології.

Пацієнтам досліджуваної групи було проведено 373 ангіографічні процедури на коронарних артеріях діаметром менше 3,0 мм.

Вік пацієнтів коливався від 62 до 73 років (в

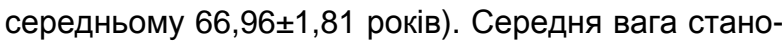

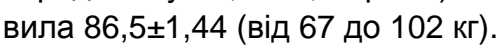

Всі пацієнти були обстежені згідно з протоколом, прийнятому в НІCCX імені М. М. Амосова НАМН України для даної категорії хворих.

У пацієнтів, яким проводилося стентування КА $(\mathrm{N}=187)$, середній діаметр істинного внутріш-

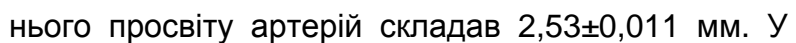
групі пацієнтів, яким була виконана перкутанна транслюмінальна балонна ангіопластика (ПТКА) $(\mathrm{N}=128)$, даний показник визначався на рівні

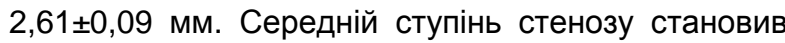
$81,3 \pm 4,07 \%$. Протяжність ураження дорівнювала $11,6 \pm 0,73$ мм.

Всі хворі I групи мали в анамнезі Q- інфраркт міокарда (IM) давністю більше 3 місяців, що дозволило діагностувати у них постінфарктний кардіосклероз. Тривалість ішемічного анамнезу понад 5 років була відзначена у 26 хворих даної групи (8,25\% випадків), до одного року - у 221 обстеженого (70,2\% випадків), від одного до двох років - у 39 пацієнтів (12,4\% випадків) і від 3-х до 4-х років у 29 осіб (9,2\% випадків).

Переважною локалізацією IM була передня, верхівкова і передньо-бічна ділянка лівого шлуночка, що відповідало ішемії по басейну лівої коронарної артерії.

Слід особливо відзначити, що важка стенокардія III-IV класів (за функціональною класифікацією стенокардії Канадського серцево-судинного товариства) поєднувалася з серцевою недостатністю у 77,1\% обстежених хворих (243 пацієнтів).

Дослідження проведене відповідно до основних біоетичних норм Гельсінської декларації Всесвітньої медичної асоціації про етичні принципи проведення науково-медичних досліджень із поправками (2000, з поправками 2008), Універсальної декларації з біоетики та прав людини (1997), Конвенції Ради Європи з прав людини та біомедицини (1997). Письмова інформована згода була отримана у кожного учасника дослідження.

Статистичний аналіз даних був здійснений за допомогою програмних пакетів Microsoft Excel XP та Statsoft Statistica 6.0.

Результати дослідження та їх обговорення. За результатами контрольного агіографічного дослідження, проведеного через 6 місяців після рентген-ендоваскулярного втручання, прогресування атеросклерозу відмічено у 82 (43,9\%) пацієнтів після проведеного стентування, і у 37 пацієнтів $(28,9 \%)$ після балонної ангіопластики $(p=0,00124)$ (табл. 1).

Таблиця 1 - Дані коронарографії віддаленого післяопераційного періоду у пацієнтів з малим діаметром коронарних артерій

\begin{tabular}{l|c|c}
\hline \multicolumn{1}{c|}{ Групи } & $\begin{array}{c}\text { Імплантація } \\
\text { стенту } \\
(\mathrm{N}=187)\end{array}$ & $\begin{array}{c}\text { Балонна } \\
\text { ангіопластика } \\
(\mathrm{N}=128)\end{array}$ \\
\hline $\begin{array}{l}\text { Прогресування } \\
\text { атеросклерозу }\end{array}$ & $82(43,9 \%)$ & $37(28,9 \%)^{*}$ \\
\hline Рестеноз & $54(28,9 \%)$ & $51(39,8 \%)^{*}$ \\
\hline
\end{tabular}

Примітка: * $-p<0,005$. 
Таблиця 2 - Частота рестенозу віддаленого періоду, в залежності від морфології вихідного пошкодження

\begin{tabular}{l|c|c|c}
\hline \multicolumn{1}{|c|}{ Морфологія вихідного пошкодження } & $\begin{array}{c}\text { Рестеноз після імплантації } \\
\text { стенту (N=54) }\end{array}$ & $\begin{array}{c}\text { Рестеноз після балонної } \\
\text { ангіопластики (N=51) }\end{array}$ & $p$ \\
\hline Стеноз < 70\% & $9(16,7 \%)$ & $20(39,2 \%)$ & 0,00137 \\
\hline Оклюзія КА & $27(50 \%)$ & $27(52,9 \%)$ & 0,7231 \\
\hline Діаметр КА >2,5 мм & $14(25,9 \%)$ & $21(41,2 \%)$ & 0,00129 \\
\hline Тип стенозу В2 і С & $22(40,7 \%)$ & $28(54,9 \%)$ & 0,00145 \\
\hline Тип стенозу А і В1 & $10(18,5 \%)$ & $14(27,5 \%)$ & 0,8293 \\
\hline Ексцентричність стенозу & $13(24,1 \%)$ & $23(45,1 \%)$ & 0,00148 \\
\hline Довжина стенозу>15 мм & $24(44,4 \%)$ & $30(58,8 \%)$ & 0,00139 \\
\hline Кальциноз КА & $22(40,7 \%)$ & $26(50,98)$ & 0,7265 \\
\hline
\end{tabular}

Примітка: КА - коронарна артерія.

При цьому кількість хворих з рестенозом після імплантації стенту склала 28,9\% (54 пацієнта), а в групі ПТКА подібне ускладення було зареєстроване в 39,8\% випадків (51 пацієнт) ( $p=0,00249)$ (табл. 1).

Тобто, повернення оклюзії КА достовірно частіше відмічалось у групі ПТКА, тоді як ознаки прогресування атеросклерозу - в групі стентування.

Ступінь рестенозу >70\% (включаючи повну обструкцію судини) переважала в обох групах, однак при конролі віддаленого результату в групі ПТКА дане ускладнення спостерігалось достовірно частіше $(p<0,005)$.

Частота рестенозу в залежності від морфології вихідного пошкодження представлена у таблиці 2.

Як видно із таблиці 2, при важкій морфології вихідного пошкодження артерій (типи В2 і С за класифікацією AНA/ACC) частота віддаленого рестенозу в групі стентування була на 14,2\% нижча, ніж у групі ПТКА ( $p=0,00145)$.

При стенозах типів А і В1 віддалені ангіографічні результати проведених процедур достовірно не відрізнялись ( $p=0,8293)$ (табл. 2).

При вихідній оклюзії КА <70\%, віддалений рестеноз після ангіографічних процедур реєструвався на $22,5 \%$ частіше у пацієнтів, яким була проведена балонна ангіопластика КА ( $p=0,00137)$ (табл. 2). Така ж тенденція спостерігалась і при ПТКА у пацієнтів з вихідним діаметром КА від 2,5 мм до 3 мм, у яких рестеноз виявлявся на 15,3\% частіше в порівнянні з однотипними пацієнтами, яким було проведено стентування КА ( $p=0,00129$ ) (табл. 2).

На наступне рестенозування вінцевих судин після рентген-ендоваскулярних операцій статистично значущий вплив надавав і тип стенозу КА. При цьому у пацієнтів з ексентричним типом стенозу, у котрих булла використана балонна ангіопластика, рестеноз у віддаленому післяопераційному періоді реєструвався на $21 \%$ частіше відносно пацієнтів 3 імплантованими стентами ( $p=0,00148)$ (табл. 2).
В ході дослідження було також встановлено, що на всій протяжності стенозованої ділянки КА $\geq 15$ мм, у пацієнтів після ПТКА у віддаденому періоді кількість рестенозів зустрічалась на 14,9\% більше, в порівнянні з аналогічними показниками, отриманими при стентуванні оклюзій ( $p=0,00139)$ (табл. 2).

Повторна ендоваскулярна процедура усунення рестенозу була успішно проведена у 37 (68,5\%) пацієнтів в групі з імплантованим стентом, у 39 (76,5\%) хворих - в групі ПТКА (р>0,05).

Інфаркт міокарда після виписки із стаціонару був зареєстрований в 1,6\% випадків (у 3 пацієнтів) після стентування, і в 6,3\% випадків (8 пацієнтів) після балонної ангіопластики ( $p=0,00435)$.

В групі ПТКА виникнення гострого ІМ у трьох пацієнтів не було пов'язано з пошкодженням артерії, на якій виконувалось втручання. Причиною їх стала оклюзія іншої судини в результаті прогресування основного захворювання. В решті випадків інфаркт міокарда (включаючи Q - IM) розвився в басейні рестенозованої артерії. Загальна кількість зареєстрованих IM, розвиток яких був пов'язаний з результатом ендоваскулярної процедури, складав 1,6\% в групі стентування, та 3,9\% випадків - в групі ПТКА ( $p=0,001425)$.

Летальні наслідки зафіксовані у 2 випадках $(1,1 \%)$ через 2,5 місяця після стентування.

\section{Висновки}

1. У пацієнтів з ексцентричним типом стенозу, у котрих була використана балонна ангіопластика, рестеноз у віддаленому післяопераційному періоді реєструвався на 21\% частіше відносно подібного контингента пацієнтів 3 імплантованими стентами.

2. Рестеноз стенозованої ділянки КА $\geq 15$ мм у віддаленому періоді зустрічався на $14,9 \%$ частіше при проведенні ПТКА.

3. Частота віддаленого рестенозу (при складній морфології вихідного пошкодження артерій) в групі стентування була на $14,2 \%$ нижча, ніж в групі ПТКА. 
Перспективи подальших досліджень. Планується подальше вивчення та аналіз безпосередніх та віддалених результатів рентген- ендоваскулярних операцій у хворих 3 ішемічною хворобою серця та малим діаметром коронарних артерій.

\section{References}

1. Go AS, Mozaffarian D, Roger VL, Benjamin EJ, Berry JD, Borden WB, Bravata DM, Dai S, Ford ES, et al. Executive summary: heart disease and stroke statistics - 2013 update: a report from the American Heart Association. Circulation. 2013; 127 (1): 143-52. PMID: 23283859. DOI: 10.1161/CIR.0b013e318282ab8f.

2. Roger VL, Go AS, Lloyd-Jones DM, Benjamin EJ, Berry JD, Borden WB, Bravata DM, Dai S, et al. Heart disease and stroke statistics - 2012 update: a report from the American Heart Association. Circulation. 2012; 125 (1): e2-e220. PMID: 22179539. PMCID: PMC4440543. DOI: 10.1161/CIR.0b013e31823ac046.

3. Handzyuk VA. Analiz zakhvoryuvanosti na ishemichnu khvorobu sertsya v Ukraini. Ukrainskyi kardiolohichnyi zhurnal. 2014; 3: 45-52. [Ukrainian]

4. Kovalenko VM, Kornatskyi VM. Rehionalni medyko-sotsialni problemy khvorob systemy krovoobihu. Dynamika ta analiz. K: MOZ Ukrainy, DU «UISD MOZ Ukrainy», 2013. 239 s. [Ukrainian].

5. Shchorichna dopovid pro stan zdorov'ya naselennya, sanitarno-epidemichnu sytuatsiyu ta rezultaty diyalnosti systemy okhorony zdorov'ya Ukrainy. 2014 rik. Za red OM Kvitashvili. K: MOZ Ukrainy, DU «UISD MOZ Ukrainy», 2013. 460 s. [Ukrainian].

6. Kawecki D, Morawiec B, Fudal M, Milejski W, Jacheć W, Nowalany-Kozielska E. Comparison of coronary artery bypass grafting with percutaneous coronary intervention for unprotected left main coronary artery disease. Yonsei Med J. 2012; 53 (1): 58-67. PMID: 22187233. PMCID: PMC3250341. DOI: 10.3349/ymj.2012.53.1.58.

7. Bangalore S, Guo Y, Samadashvili Z, Blecker S, Xu J, Hannan EL. Everolimus eluting stents versus coronary artery bypass graft surgery for patients with diabetes mellitus and multivessel disease. Circ Cardiovasc Interv. 2015; 8 (7): e002626. PMID: 26156152. DOI: 10.1161/CIRCINTERVENTIONS.115.002626.

8. Patel VG, Michael TT, Mogabgab O, Fuh E, Banerjee A, Brayton KM, Cipher DJ, Abdullah SM, Brilakis ES. Clinical, angiographic, and procedural predictors of periprocedural complications during chronic total occlusion percutaneous coronary intervention. J Invasive Cardiol. 2014; 26 (3): 100-5. PMID: 24610502.

9. Oliveira FR, Mattos LA, Abizaid A, Abizaid AS, Costa JR, Costa R, Rodolfo Staico, Botelho R, Sousa JE, Sousa A. Miniaturized self-expanding drug-eluting stent in small coronary arteries: late effectiveness. Arq Bras Cardiol. 2013; 101 (5): 379-87. PMCID: PMC4081161. doi: 10.5935/abc.20130199.

10. Teirstein PS, Meredith IT, Feldman RL, Charles A, Cannon LA, Lee TC, Dens J, Dubois CL, Mooney MR, Pompili VJ, et al. Two-year safety and effectiveness of the platinum chromium everolimus-eluting stent for the treatment of small vessels and longer lesions. Catheter Cardiovasc Interv. 2015; 85 (2): 207-15. https://doi.org/10.1002/ccd.25565.

11. Diletti R, Farooq V, Girasis C, Bourantas C, Onuma Y, Heo JH, Gogas BD, van Geuns R-J, Regar1 E, et al. Clinical and intravascular imaging outcomes at 1 and 2 years after implantation of absorb everolimus eluting bioresorbable vascular scaffolds in small vessels. Late lumen enlargement: does bioresorption matter with small vessel size? Insight from the ABSORB cohort B trial. Heart. 2013; 99 (2): 98-105. http://dx.doi.org/10.1136/heartjnl-2012-302598.

12. Cortese B, Micheli A, Picchi A, Coppolaro A, Bandinelli L, Severi S, Limbruno U. Paclitaxel-coated balloon versus drugeluting stent during $\mathrm{PCl}$ of small coronary vessels, a prospective randomised clinical trial. The PICCOLETO study. Heart. 2010; 96 (16): 1291-6. PMID: 20659948. DOI: 10.1136/hrt.2010.195057.

УДК 616.12-005.4-089.1:616.132.2-007.271]-036.8

\section{ОТДАЛЕННЫЕ КЛИНИКО-АНГИОГРАФИЧЕСКИЕ РЕЗУЛЬТАТЫ РЕКАНАЛИЗАЦИИ КОРОНАРНЫХ АРТЕРИЙ МАЛОГО ДИАМЕТРА У ПАЦИЕНТОВ С ИШЕМИЧЕСКОЙ БОЛЕЗНЬЮ СЕРДЦА}

Аксёнов Е. В., Гуменюк Б. М., Головенко В. Б.

Резюме. Работа посвящена изучению результатов эндоваскулярных процедур при реваскуляризации коронарных артерий малого диаметра.

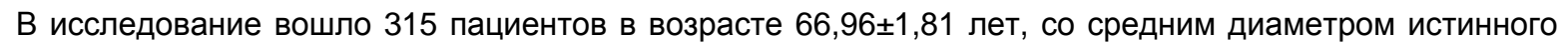

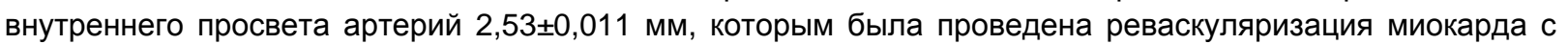
помощью стентирования или путем перкутанной транслюминальной баллонной ангиопластики.

В результате проведенных исследований было установлено, что у пациентов с эксцентричным типом стеноза, у которых была использована баллонная ангиопластика, рестеноз в отдаленном послеоперационном периоде регистрировался на $21 \%$ чаще относительно подобного контингента пациентов с имплантированными стентами. К тому же, рестеноз стенозированного участка коронарной артерии >15 мм, в отдаленном периоде встречался на 14,9\% чаще при проведении перкутанной транслюминальной баллонной ангиопластики. Частота удаленного рестеноза (при сложной морфологии исходного повреждения 
артерий) в группе стентирования была на 14,2\% ниже, чем в группе перкутанной транслюминальной баллонной ангиопластики.

Ключевые слова: ишемическая болезнь сердца, реканализация коронарных артерий.

UDC 616.12-005.4-089.1:616.132.2-007.271]-036.8

Long-term Clinical and Angiographic Results of Recanalization

of Small Diameter Coronary Arteries in Patients with Ischemic Heart Disease

Aksenov E. V., Gumeniuk B. M., Golovenko V. B.

Abstract. Cardiovascular disease is one of the leading causes of death worldwide. The main contribution to its structure belongs to ischemic heart disease (IHD), which has become the greatest threat to the health of the population all over the world.

The purpose of the study is to study of the results of endovascular procedures in the revascularization of coronary arteries of small diameter.

Materials and methods. The study included 315 patients aged $66.96 \pm 1.81$ years, with a mean diameter of the true internal lumen of the arteries of $2.53 \pm 0.011 \mathrm{~mm}$, which had a revascularization of the myocardium through stenting or percutaneous transluminal balloon angioplasty.

In patients undergoing stenting of $\mathrm{Ca}(\mathrm{N}=187)$, the mean diameter of the true internal lumen of arteries was $2.53 \pm 0.011 \mathrm{~mm}$. In the group of patients who used percutaneous transluminal balloon angioplasty (PTCA) $(\mathrm{N}=128)$, this indicator was determined at $2.61 \pm 0.09 \mathrm{~mm}$. The average degree of stenosis was $81.3 \pm 4.07 \%$. The length of the defeat was $11.6 \pm 0.73 \mathrm{~mm}$.

All patients and groups had the history of Q-infarction of the myocardium (IM) of more than 3 months, which made it possible to diagnose postinfarction cardiosclerosis. Duration of ischemic history more than 5 years was noted in 26 patients of this group (8.25\% of cases), up to one year - in 221 patients ( $70.2 \%$ of cases), from one to two years - in 39 patients (12.4\% cases) and from 3 to 4 years - in 29 people $(9.2 \%$ of cases).

Results and discussion. As a result of the studies, it was found that in patients with eccentric type of stenosis who used balloon angioplasty, restenosis in the remote postoperative period was $21 \%$ more frequent, compared to a similar contingent of patients with implanted stents. In addition, the restenosis of the stenosed area of the coronary artery $>15 \mathrm{~mm}$, in the distant period, was found to be $14.9 \%$ more commonly when percutaneous transluminal balloon angioplasty was performed. And the frequency of remote restenosis (with complex morphology of initial damage of the arteries) in the stenting group was $14.2 \%$ lower than in the group of percutaneous transluminal balloon angioplasty.

Conclusions. Restenosis in the remote postoperative period was $21 \%$ more frequent in patients with eccentric stenosis for whom balloon angioplasty was used than in patients with implanted stents. At the same time restenosis of the stenosed area of $C A>15 \mathrm{~mm}$ in the distant period was found to be $14.9 \%$ more frequent during PTCA. The frequency of remote restenosis (with complicated morphology of basal damage of arteries) in the stenting group was $14.2 \%$ lower than in the PTCA group. Thus, we plan to further study and analyze the direct and long-term results of $\mathrm{X}$-ray and endovascular operations in patients with coronary artery disease and small coronary artery diameter.

Keywords: recanalization coronary arteries, ischemic heart disease.

Стаття надійшла 9.11.2017 p Рекомендована до друку на засіданні редакційної колееії після рецензування 